\title{
KOMPOSISI EFEK SPONTAN CAT AIR DENGAN SULUR TRADISIONAL YOGYAKARTA PADA PENCIPTAAN LUKISAN
}

\author{
Deni Junaedi ${ }^{1}$ (denilonghistory@gmail.com, Jurusan Seni Murni Fakultas Seni Rupa Institut Seni Indonesia Yogyakarta) \\ Adnan Aditya K. ${ }^{2}$ (Jurusan Seni Murni Fakultas Seni Rupa Institut Seni Indonesia Yogyakarta)
}

\begin{abstract}
ABSTRAK
Penelitian "Komposisi Efek Spontan Cat Air dengan Sulur Tradisional Yogyakarta pada Penciptaan Lukisan" ini paling tidak memiliki tiga urgensi untuk pendidikan seni lukis maupun dunia seni lukis pada umumnya. Pertama, perpaduan efek spontan cat air yang terjadi dengan sendirinya dengan sulur tradisional Yogyakarta yang memiliki pakem akan menghasilkan dinamika bentuk yang diperlukan untuk penciptaan seni lukis. Kedua, sulur biasanya menjadi penghias barang fungsional, dan dalam penelitian ini ia diangkat sebagai pembangkit pengalaman estetis itu sendiri; dengan kata lain 'sulur dihadirkan sebagai sulur itu sendiri', bukan sekedar penghias yang menempatkannya sebagai aspek kedua setelah barang yang dihiasi. Ketiga, penelitian ini menerapkan kaidah langgam seni postmodern shock of the old, bukan shock of the new. Rumusan penciptaan dalam penelitian ini adalah bagaimana mengomposisi efek spontan cat air di kertas dengan bentuk sulur tradisional Yogyakarta untuk penciptaan lukisan. Data sulur diperoleh dengan kajian pustaka maupun observasi, yaitu di Keraton Kasultanan Yogyakarta, Makam Raja-Raja Mataram Kotagede, Makam Raja-Raja Imogiri, Museum Sonobudoyo, Taman Sari, Museum Kereta Keraton, dan Benteng Vredeburg. Hasil penciptaan lukisan kombinasi efek spontan cat air dengan sulur tradisional ini dikerjakan dengan dua cara yang berbeda. Cara pertama adalah menentukan bentuk sulur lalu diberi efek spontan cat air. Sebaliknya, cara kedua adalah membuat efek spontan cat air terlebih dahulu kemudian direspon dengan sulur.
\end{abstract}

Kata Kunci: lukisan, sulur, efek spontan cat air, Yogyakarta

ABSTRACT

This research, "Compositions between Watercolor Effects and Yogyakarta Traditional Sulurs for Painting Creations", has at least three urgencies for painting educations and art worlds generally. First, on the one hand, watercolor effects give spontaneous forms; on the other hand, Yogyakarta traditional Sulurs (spiral forms of floral ornamens) have certain patterns. Combinations of both of them produce dynamic compositions needed for creating paintings. Second, the function of sulurs usually are for decorating things, such as ornamens on buidings, furniture, or book illuminations; in this case, sulur is as the second thing. Meanwhile, in this research, sulurs are used for arousing aesthetic experiences; it is as itself. Third, this study applies the postmodern art value 'shock of the old', not 'shock of the new'. The research question is how to compose the spontaneous watercolor effects with Yogyakarta traditional sulurs for painting creations. Sulur data is obtained by literature review and observations at Yogyakarta Sultanate Palace, Tomb of the Kings of Mataram Kotagede, 
Tomb of the Kings of Imogiri, Sonobudoyo Museum, Taman Sari, Keraton Carriage Museum, and Vredeburg Fort. The result of this research is, the combinations of watercolor effects and sulur can be created in two different ways. The first way is determining the shape of the sulurs then given with watercolor effects. Instead, the second way is creating watercolor effects first then responded with sulurs.

Keywords: painting, sulur, spontaneous watercolor effect, Yogyakarta

\section{PENDAHULUAN}

Perpaduan atau komposisi efek spontan cat air dengan sulur tradisional Yogyakarta pada lukisan akan menghasilkan dinamika bentuk. Cat air menjanjikan efek spontan atau bentuk yang terjadi dengan sendirinya, tidak terduga; sedangkan sulur tradisional dibuat di bawah pakem yang seringkali perlu diikuti dengan ketat. Sulur merupakan bentuk ornamen tumbuhan yang memiliki ritme lengkung, menjalar seperti spiral. Perpaduan dua hal yang berbeda ini, antara bentuk yang cenderung tidak terprediksi dengan bentuk yang penuh aturan, menjanjikan karya seni lukis yang tidak terkesan statis.

Perihal cat air di kertas, media ini menjanjikan eksplorasi teknik. Hal Ini dapat dilakukan dengan memainkan tingkat kebasahan atau kekeringan kertas maupun kuas. Paling tidak, kombinasi ini menghasilkan: wet-on-wet (basah di basah), yaitu kuas dengan kondisi cat air yang relatif encer untuk diterapkan pada kertas yang basah; wet-on-dry (basah di kering), yaitu kuas dengan kondisi cat air yang relatif encer di kertas kering; dry-on-wet (kering di basah), yaitu kuas dengan kondisi cat air yang relatif kental di kertas basah; maupun dry-on-dry (kering di kering), yaitu kuas dengan kondisi cat air yang relatif kental di kertas kering. Efek spontanitas terjadi terutama pada teknik weton-wet.

Perihal sulur Yogyakarta, kota Yogyakarta yang bersejarah menjanjikan berbagai penerapan sulur. Di ragam artefak yang ditinggalkan para pemimpin Kasultanan
Yogyakarta, sulur banyak diterapkan. Sulur dapat ditemui di Keraton Yogyakarta, Makam Raja-Raja Mataram Kotagede, Makam RajaRaja Imogiri, Museum Sonobudoyo, Taman Sari, dan berbagai tempat lainnya. Sulur diaplikasikan di bangunan, kereta, gamelan, kitab, bahkan pada meriam.

Penerapan sulur pada lukisan menjadi langkah yang berkesinambungan dengan penerapan pada benda-benda tersebut. Sekaligus, penerapan sulur pada lukisan memiliki perbedaan esensial dibandingkan dengan penerapan pada berbagai benda tadi. Bangunan, kereta, gamelan, kitab, atau meriam merupakan benda fungsional, dan sulur di artefak ini berperan sebagai penghias benda fungsional tersebut. Dalam lukisan, yang merupakan karya seni murni, yang tidak memiliki nilai fungsional selain untuk membangkitkan pengalaman estetis, sulur tidak menjadi unsur kedua setelah fungsi benda. Akan tetapi, sulur menjadi aspek utama untuk membangkitkan pengalaman estetis spektator, dengan kata lain sulur dihadirkan sebagai 'sulur itu sendiri'.

Selain itu, perpaduan antara efek spontan cat air yang biasa dimanfaatkan oleh seni modern, dengan sulur yang umumnya digunakan oleh seniman tradisional, akan menjadi bahasa ungkap postmodern. Karya seperti ini tidak lagi memakai kaidah shock of the new atau jerih payah mengejar kebaruan, tetapi shock of the old atau memanfaatkan hal lama untuk meraih perhatian.

Upaya-upaya seperti ini - yaitu: perpaduan antara bentuk spontan dengan bentuk pakem yang diharapkan menghasilkan 
dinamika, penempatan sulur yang biasanya menjadi penghias barang fungsional untuk dihadirkan 'hanya' sebagai pembangkit pengalaman estetis, dan penerapan kaidah langgam seni postmodern shock of the old merupakan penelitian yang relevan untuk lingkungan pendidikan seni lukis, sebagaimana pendidikan tinggi seni lukis di Institut Seni Indonesia Yogyakarta. Eksplorasi bentuk (form) maupun isi (content) seni lukis perlu diusahakan agar perkembangan seni lukis memiliki terobosan-terobosan baru.

Untuk itu, penelitian penciptaan seni ini mengajukan rumusan masalah, yaitu bagaimana mengomposisi efek spontan cat air di kertas dengan bentuk sulur tradisional Yogyakarta untuk penciptaan lukisan.

\section{Tinjauan Pustaka}

Penelitian yang secara spesifik membahas komposisi efek spontan cat air dengan sulur tradisional Yogyakarta pada penciptaan lukisan belum ada. Namun demikian, penelitian tentang sulur di Yogyakarta, yang berada dalam kategori yang lebih luas, yaitu ornamen, telah dibuat. Selain itu, kajian tentang sulur dalam lukisan yang digabungkan dengan bentuk-bentuk lain telah ada, tetapi lukisan-lukisan ini tidak menggunakan media cat air. Berikut ini beberapa penelitian terdahulu.

Penelitian tentang ornamen yang antara lain membahas sulur di Yogyakarta adalah "Bentuk dan Makna Simbolik Ornamen Ukir pada Interior Masjid Gedhe Yogyakarta" oleh Jeksi Dorno (2014:107-8). la mencatat sulur atau tumbuhan yang menjalar dengan untaian daun dan pucuk batang muda juga disebut motif lunglungan. Ukiran di Masjid Gedhe Yogyakarta pada umumnya berbentuk motif flora atau tumbuh-tumbuhan. Lunglungan berasal dari kata ulung-ulung dan tetulung yang bermakna dermawan dan menolong. Menurutnya, lunglungan mempunyai makna bahwa seorang muslim harus mempunyai jiwa sosial yang baik, gemar membantu sesame, dan mempunyai sifat dermawan. Sulur atau lung-lungan mengandung juga harapan agar kehidupan dan rezeki selalu datang. Selain untuk hiasan di masjid, lunglungan juga menjadi salah satu motif batik.

Sementara itu, penggunaan ornament termasuk sulur, telah ada dalam seni lukis kontemporer. Saat meneliti karya-karya Entang Wiharso, Amanda Katherine Rath (2010:123-25) mengungkap bahwa perupa Indonesia kelahiran 1967 itu menggunakan ornamen sebagai petanda protes melawan apa yang mungkin dan apa yang tidak mungkin dalam seni kontemporer. Amanda mengutip pernyataan Entang bahwa ornamen dibenci dalam wacana seni; dianggap berlebihan, tidak ada arti dan tujuannya. Entang terganggu oleh hal ini, maka ia berusaha membuat guncangan dengan visual yang biasa dicibir.

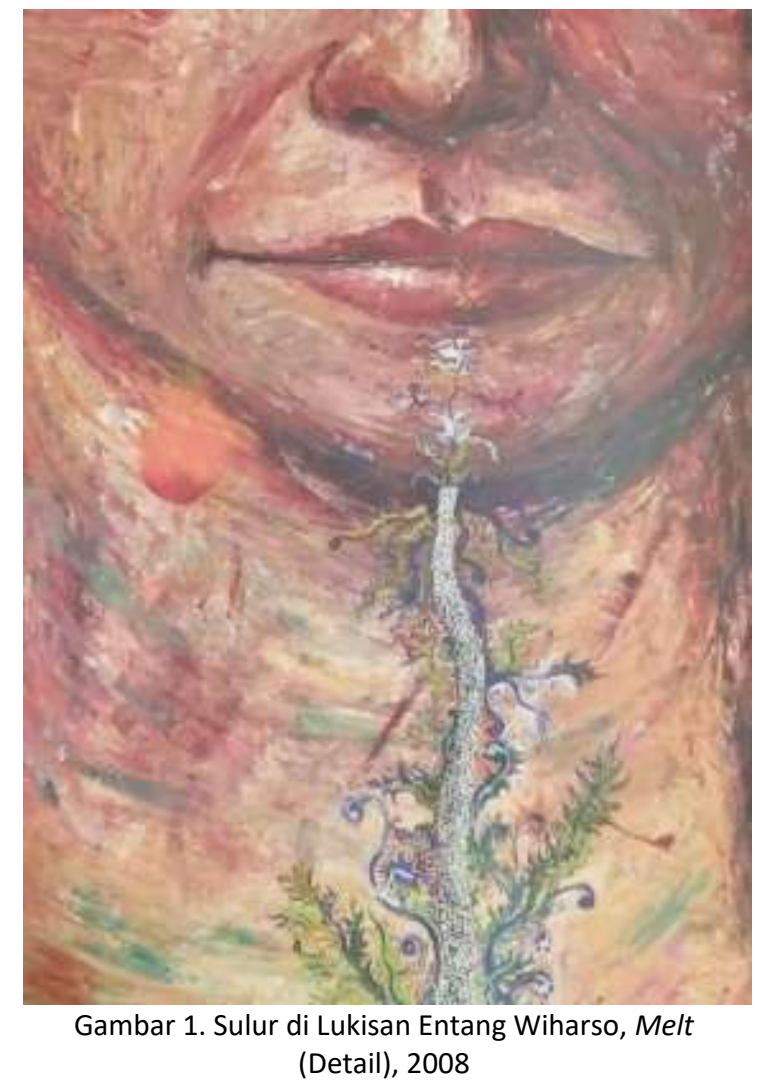

(Sumber: Katalog Love Me or Die: Entang Wiharso, 2010: 122) 


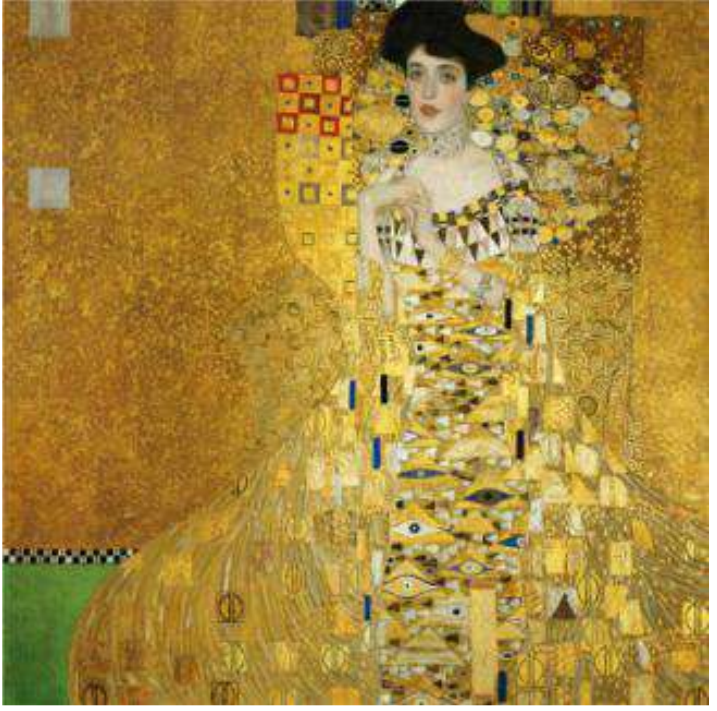

Gambar 2. Ornamen pada Lukisan Gustav Klimt, Portrait of Adele Bloch-Bauer I, 1907 (Sumber: Urdea, 2015: 91)

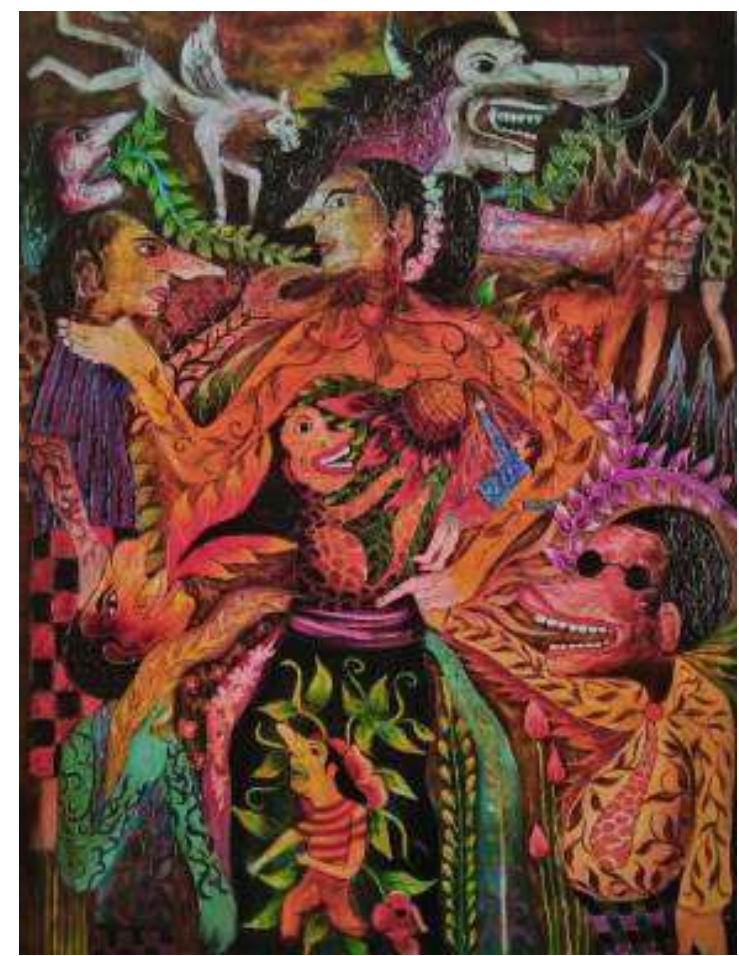

Gambar 3. Ornamen dalam Lukisan Nasirun, Teraniaya, 2014, Cat Minyak di Kanvas, $200 \times 150 \mathrm{~cm}$ (Sumber: Wisetrotomo, 2016: 236)

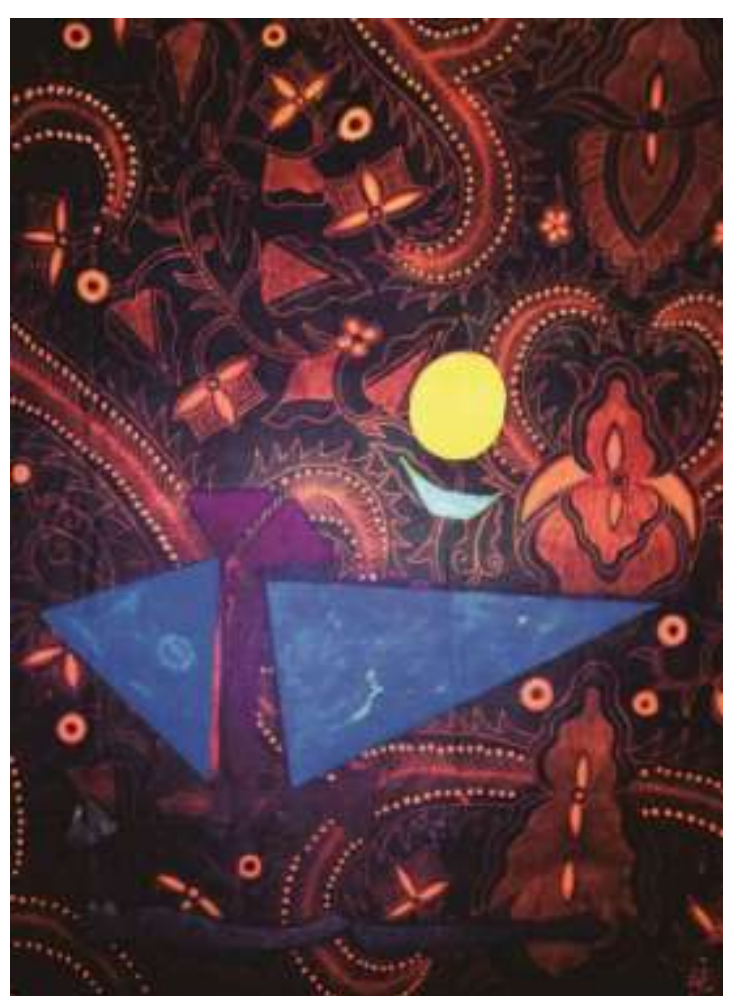

Gambar 4. Batik Dinamika Ruang Fajar Sidik di Atas Motif Semen

(Sumber: Aruman, 2015: 55)

Sebelumnya, Gustav Klimt juga mengeksplorasi ornamen untuk lukisanlukisannya. la memadukannya dengan bentuk realistik.Olimpia Urdea (2015:91), dalam artikel "Klimt, from Painting to Fashion" di jurnal Annals of the University of Oradea Fascicle of Textiles-Leatherwork mencatat bahwa karya Klimt bertipikal Art Nouveau. Figur perempuan dalam karyanya menyatu dengan ornamen yang mengingatkan pada seni lukis Mesir Kuno. Motif dekoratif tersusun baik secara repetitif, simetris, berganti-ganti, terhubung, maupun saling tumpang-tindih. Klimt menggunakan media cat minyak dengan dominasi warna emas.

Perupa lain yang intensif mengolah ornamen dalam karyanya adalah Nasirun. Dalam "Run Suluk Pikir Jiwa dan Raga" di katalog Run: The Journey of Mind, Soul and Body", Wisetrotomo (2016: 86) mencatat bahwa keterampilan ornamentasi Nasirun diperoleh saat belajar seni rupa di Sekolah Menengah Seni Rupa Yogyakarta Jurusan Seni Kriya, dengan tahun kelulusan 1987, lalu dilanjutkan ke Jurusan Seni Lukis Fakultas Seni Rupa dan Desain ISI Yogyakarta. Kemampuan 
Nasirun dalam motif maupun teknik batik diintegrasikan dalam lukisan.

Kemudian, penelitian yang mengaitkan motif tradisional dengan elemen artistik lukisan modern adalah "Batik Postmodern (Pengadaptasian Elemen Artistik Lukisan Modern Indonesia dalam Teknik dan Motif Batik Tradisional Yogyakarta)" oleh Aruman, Deni Junaedi, dan Isbandono Hariyanto (2015). Penelitian Hibah Bersaing tahun 2014 - 2015 ini menciptakan motif batik postmodern melalui pengadaptasian elemen artistik lukisan modern Indonesia dengan motif dan teknik batik tradisional.

Berbagai penciptaan karya seni rupa yang memadukan sulur maupun ornamen di atas tidak terkait dengan teknik cat air. Dengan demikian, penelitian yang berusaha memadukan efek spontan cat air dengan motif sulur tradisional Yogyakarta ini memiliki perbedaan dengannya.

\section{Data Penelitian}

Data penelitian, yaitu informasi tentang sulur Yogyakarta, diperoleh melalui kajian pustaka maupun obesrvasi ke beberapa lokasi di Yogyakarta. Lokasi yang dipilih terutama lokasi yang bersejarah bagi Yogyakarta, yaitu: Keraton Ngayogyakarta Hadiningrat (Keraton KasultananYogyakarta), Makam Raja-Raja Mataram Kotagede, Makam Raja-Raja Imogiri, Museum Sonobudoyo, Taman Sari, Museum Kereta Keraton, maupun Benteng Vredeburg.

\section{Sulur Yogyakarta}

Sulur merupakan salah satu ornamen bermotif tumbuhan, namun tidak semua ornamen bermotif tumbuhan adalah sulur, terdapat juga motif pohon hayat maupun bunga. Bentuk dasar tumbuhan dalam sulur adalah lengkung atau menjalar seperti spiral. Sebagaimana ornamen lainnya yang memiliki fungsi menghias - ornamen berasal dari bahasa latin ornare yang berarti menghias sulur juga untuk memperindah suatu benda (Sunaryo, 2009: 153-70).

Pada dasarnya, motif tumbuhan terdiri atas: daun pokok, ikal daun (ulir), tunas daun (trubus), kelopak daun (angkup), bunga, kuncup, tanaman yang menjulur (lung).
Secara lebih rinci, dalam sulur Yogyakarta terdapat: ceplok atau bunga yang berbentuk bulat, lipatan daun, maupun pecahan atau belahan kecil pada daun, maupun benangan atau garis daun (Sunaryo, 2009: 165).

Namun demikian, sulur, karena diterapkan di banyak sekali ragam benda, bentuknya relatif fleksibel. Sulur dapat diterakan di bagian bangunan, kitab, pakaian, gamelan, kereta, bahkan meriam. Ornamen ini luwes mengikuti bentuk benda yang dihiasi.

Selain perihal bentuk, sulur terkadang dikaitkan dengan makna tertentu. Sulur juga disebut lunglungan. Lunglungan berasal dari kata ulung-ulung atau tetulung yang bermakna 'dermawan' atau 'menolong'. Sulur juga mewakili harapan agar rezeki datang berkesinambungan tanpa pernah putus (Dorno, 2014: 107-8).

Hampir seluruh situs budaya di Yogyakarta yang digunakan sebagai tempat observasi untuk penelitian ini ditebari sulursulur, yaitu Keraton Kasultanan Yogyakarta, Makam Raja-Raja Mataram Kotagede, Makam Raja-Raja Imogiri, Museum Sonobudoyo, Taman Sari, maupun Museum Kereta Keraton. Masjid Gedhe Kauman juga penuh dengannya. Hanya Benteng Vredeburg yang dulu digunakan penjajah Belanda tidak menggunakan sulur-sulur pada bangunannya. Adapun artefak yang dikoleksi museum itu tentu saja ada yang dihiasi dengan sulur.

Bahwa Yogyakarta memiliki kekayaan sulur tradisional dapat dipahami secara historis. Kota ini memiliki sejarah panjang, rakyat maupun pengusanya mempraktikkan penciptaan karya seni. Keraton Ngayogyakarta Hadiningrat didirikan oleh Sri Sultan Hamengku Buwono I tanggal 7 Oktober 1756. Sultan pertama ini memiliki perhatian pada seni. la sangat peduli terhadap visual wayang kulit maupun arsitektur Taman Sari. Sultan penerusnya pun memperhatikan persoalan seni, termasuk pada ornamen batik.

Berikut ini adalah beberapa artefak di Yogyakarta yang dihiasi dengan sulur:

\section{a. Sulur pada Bangunan}

Sulur banyak dimanfaatkan untuk menghiasi bangunan. Pintu, tiang, maupun 
langit-langit menjadi tempat favorit untuk sulur. Sulur pada dinding biasanya dalam bentuk relief.

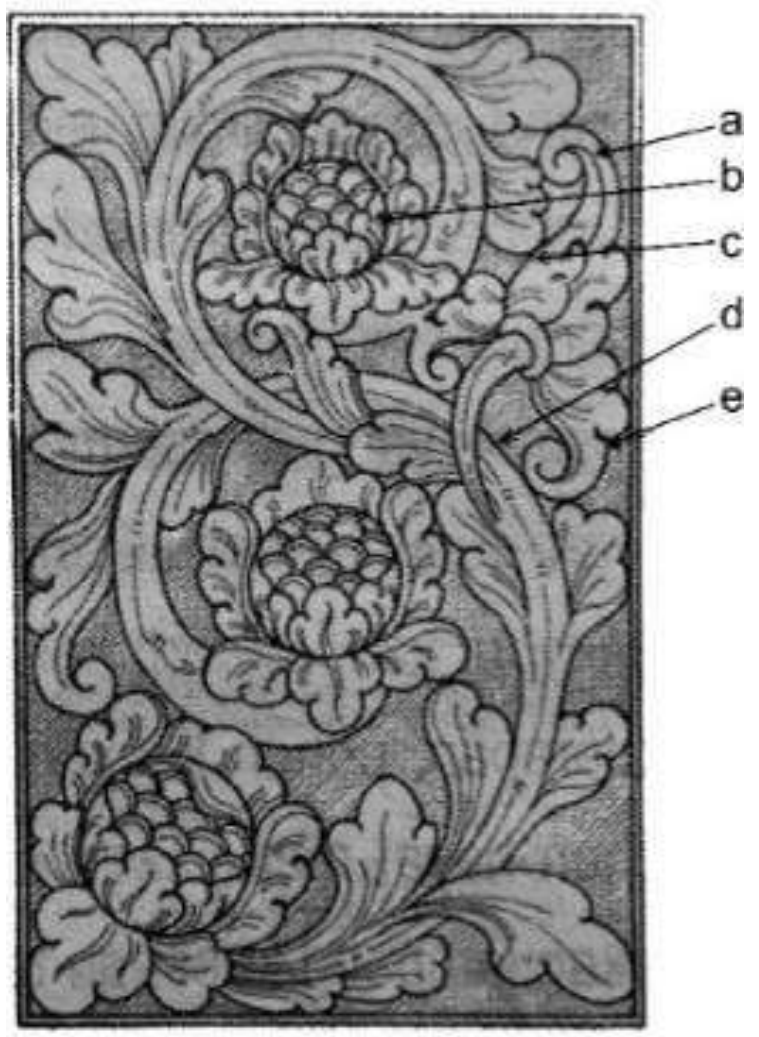

Gambar 5. Sulur Yogyakarta,

(a) Benangan, (b) Ceplok, (c) Lipatan Daun, (d) Lung, dan (e) Pecahan

(Sumber: Sunaryo, 2009: 165)

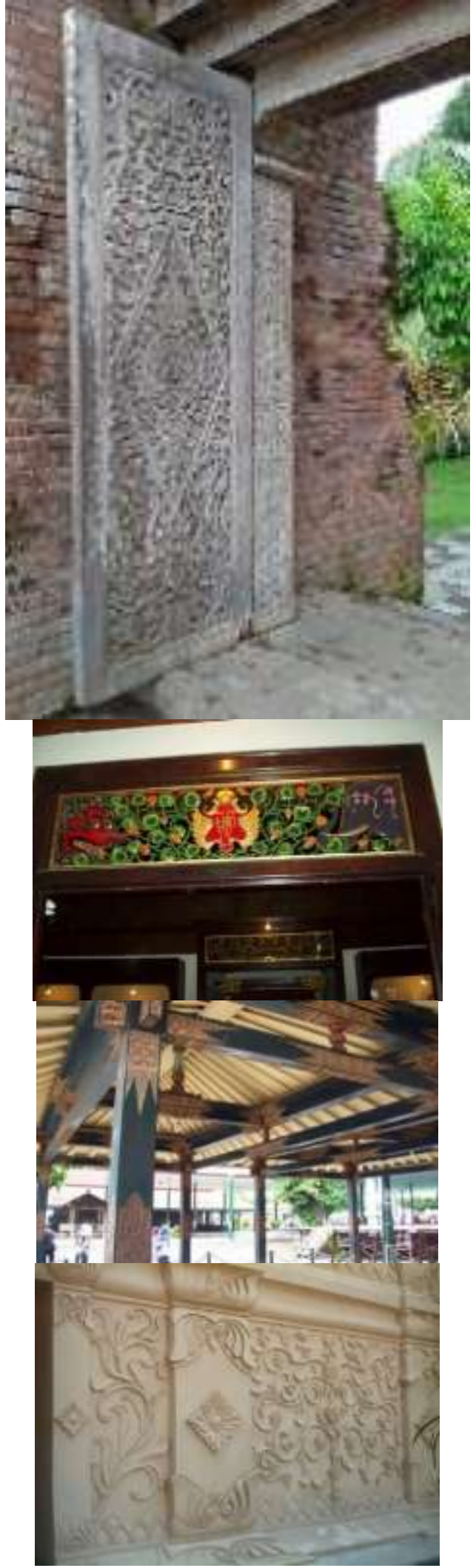

Gambar 6. Sulur pada Bangunan: 1) Pintu di Makam Raja-Raja Mataram Kotagede;

2) Pintu di Museum Senisono; 3) Tiang di Keraton Yogyakarta; 4) Dinding di Tamansari 


\section{b. Sulur pada Kereta}

Kereta sebagai alat tranportasi tradisional Keraton Kasultanan Yogyakarta juga tidak lupa dihias dengan sulur-sulur. Terkadang sulur dibuat dengan cat pada tubuh kereta, seperti yang ada di Kereta Kyai Jatayu; diukir di tubuh kereta, termasuk pada kayu pijakan untuk naik sebagaimana pada Kereta Kanjeng Nyai Jimad; maupun pada lampu kereta seperti pada Kereta Kyai Jolodoro.

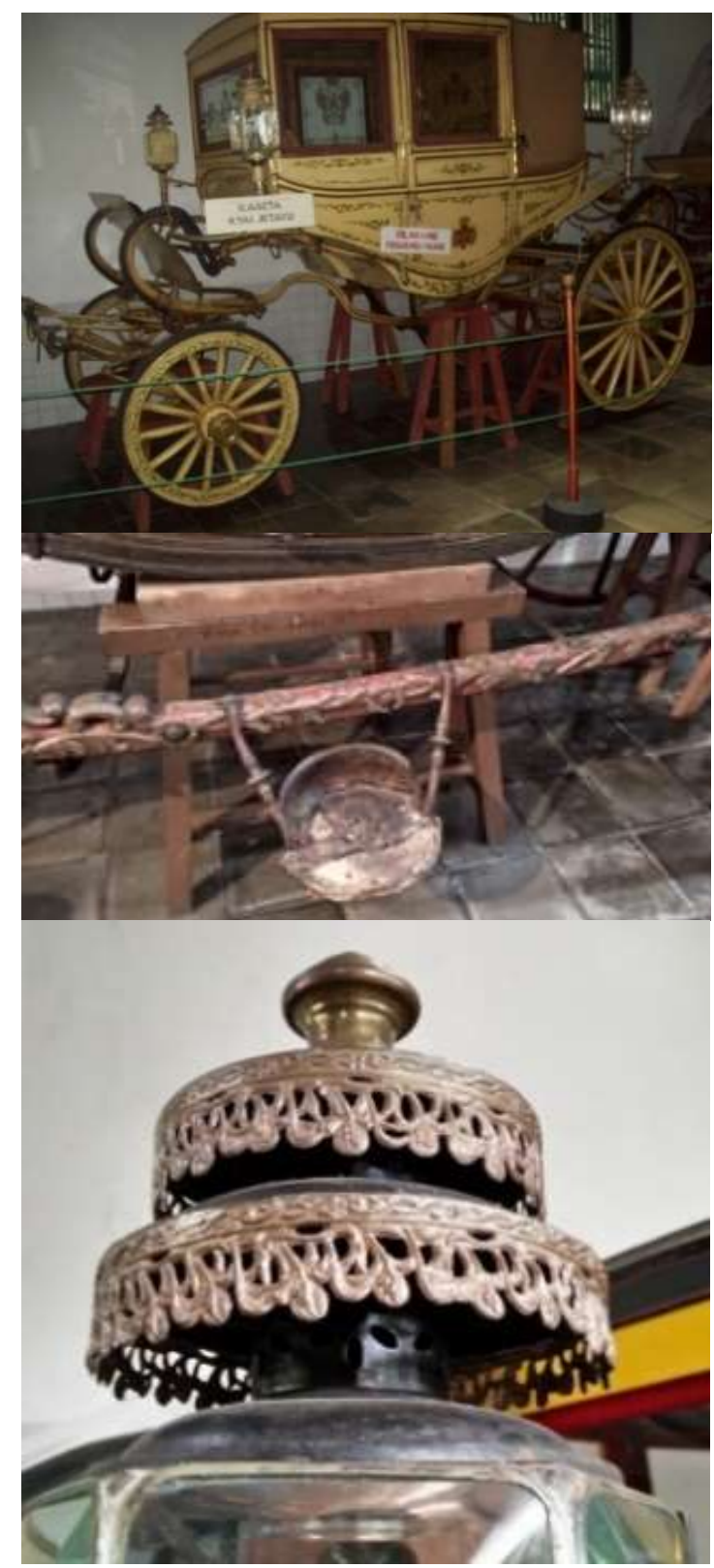

Gambar 7. Sulur di Kereta Tradisional Koleksi Museum Kereta Yogyakarta:

1) Sulur di Tubuh Kereta Kyai Jatayu; 2) Sulur di Pijakan Kereta Kanjeng Nyai Jimad;

3) Sulur di Lampu Kereta Kyai Jolodoro

\section{c. Sulur pada Perabot}

Perabot diartikan dalam arti luas, baik perabot untuk peribadatan, peperangan, pergelaran, maupun kebutuhan lainnya. Mimbar di Masjid Gedhe dipenuhi dengan ukiran sulur yang dicat keemasan. Gamelan baik gamelan yang ada di keraton maupun Gamelan Kyai-Nyai Riris Manis di Sonobudoyo dihias pada kayu dudukannya. Bahkan, meriam yang terbuat dari baja tidak luput dari hiasan sulur.

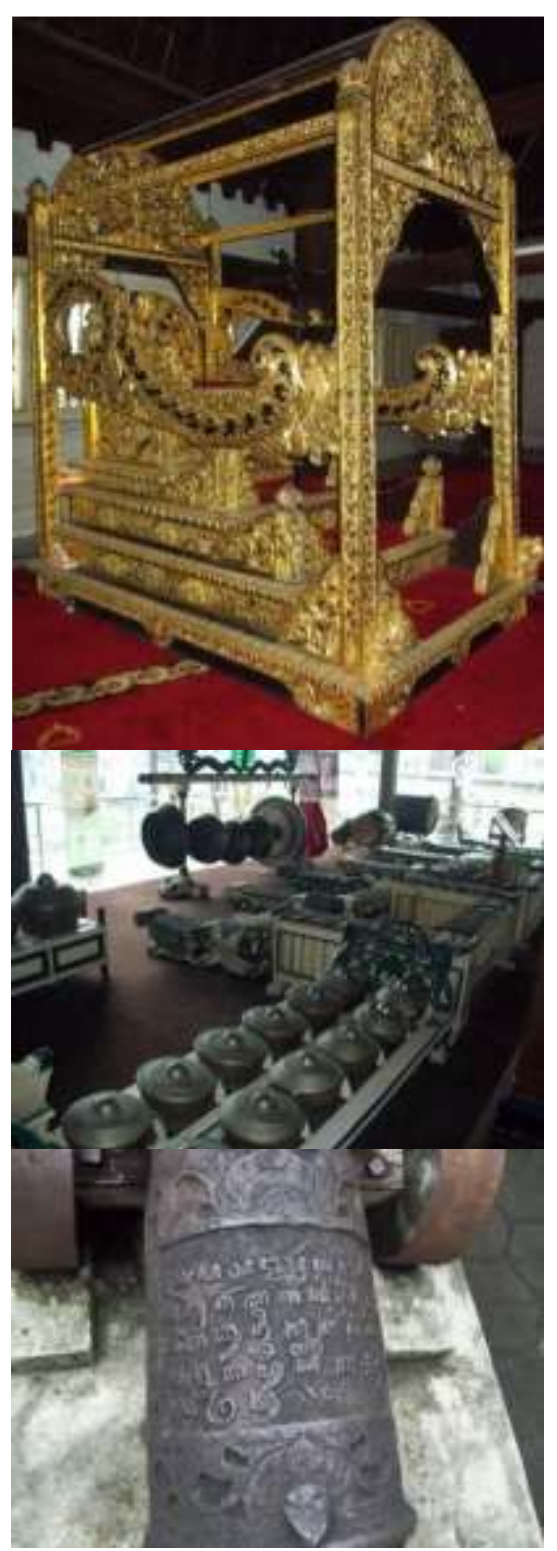

Gambar 8. Sulur di Perabot: 1) Mimbar Masjid Gedhe Kauman; 2) Gamelan Kyai-Nyai Riris Manis di Sonobudoyo; 3) Meriam di Museum Sonobudoyo 


\section{d. Sulur pada Buku}

Sulur juga dipakai pada manuskrip kuno, digunakan sebagai frame tulisan yang ada. Seni untuk menghias halaman buku seperti ini biasanya disebut iluminasi. Adapun tulisan dan bahasa yang digunakan pada koleksi Museum Sonobudoyo ialah bahasa dan huruf Arab, bahasa Jawa dengan huruf Arab (Arab pegon), maupun bahasa Melayu dengan huruf Arab.

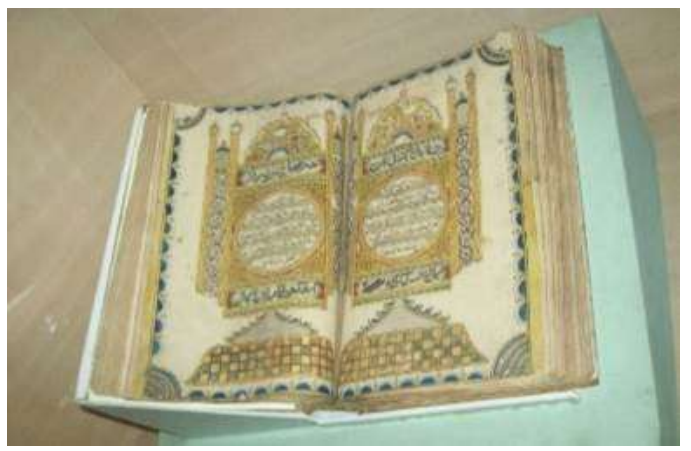

Gambar 9. Sulur pada kitab di Museum Sonobudoyo.

\section{Efek Spontan Cat Air}

Joe Garcia (2002: 36-37) dalam Mastering the Watercolor Wash merumuskan bahwa terdapat empat teknikdalam pembuatan dasar cat air, yaitu: datar (flat), gradasi (gradated), basah pada basah (wetinto-wet), dan lelehan (streaked). Datar merupakan pembuatan warna satu nada dalam suatu bidang. Gradasi adalah perubahan tonalitas atau gelap terang warna secara berangsur dalam suatu permukaan. Basah pada basah merupakan teknik peneraan cat air pada permukaan kertas yang telah dibasahi, sehingga warna akan terbentuk atau tercampur secara spontan. Lelehan adalah teknik yang dibuat dengan cara peneraan cat air di atas kertas basah lalu salah satu sisi kertas diangkat agar cat air tersebut mengalir ke arah yang dikehendaki.

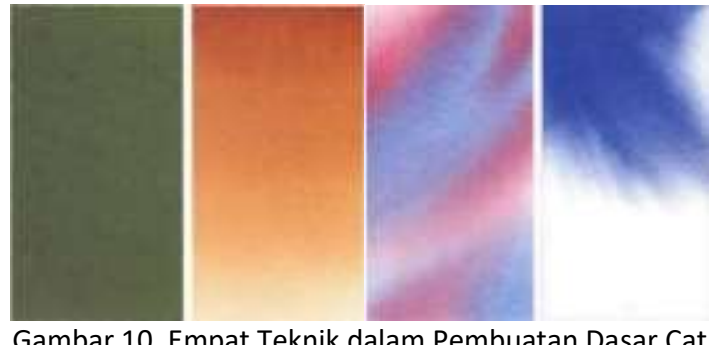
Air, yaitu:

Datar (Flat), Gradasi (Gradated), Basah pada Basah (Wet-into-Wet), dan Lelehan (Streaked) (Sumber: Garcia, 2000: 36-37)

Sebelum memadukan sulur dengan efek cat air, eksplorasi teknik cat air telah mengawali penelitian ini. Karena bersifat spontan, efek tersebut tidak sepenuhnya dapat dikontrol. Detail bentuknya terjadi dengan sendirinya, kreator hanyalah memprediksi atau mengasumsikan bentuk yang akan muncul lalu mengondisikan dengan teknik yang sesuai.

Teknik adalah metode penciptaan karya seni (Mittler and Ragans, 2005: 30-38). Ragam efek spontan cat air dikerjakan dengan teknik tertentu. Berikut ini adalah teknik yang pernah diterapkan oleh peneliti untuk dimanfaatkan pada penelitian ini, yaitu: teknik basah pada basah, teknik lelehan basah pada basah, teknik lelehan basah pada kering, teknik cipratan, teknik tiupan, dan teknik penutupan.

\section{Teknik Basah pada Basah}

Lukisan Benih-Benih Berterbangan berikut ini menggunakan teknik basah pada basah (wet on wet). Karya dikerjakan dalam posisi terlentang. Cara pembuatannya adalah dengan membasahi kertas lalu menggoreskan warna yang terhitung cair, dalam hal ini warna biru dan ungu. Selanjutnya, penyemprotan air bersih dilakukan pada bagian-bagian tertentu yang diinginkan berwarna terang. Efek keadaan basah ini membuat kertas bergelombang, meskipun sudah dibentang dengan isolasi. Bagian yang ada dipuncak gelombang akan mengalirkan cat, ini mengakibatkan warnanya menjadi terang setelah kering. 

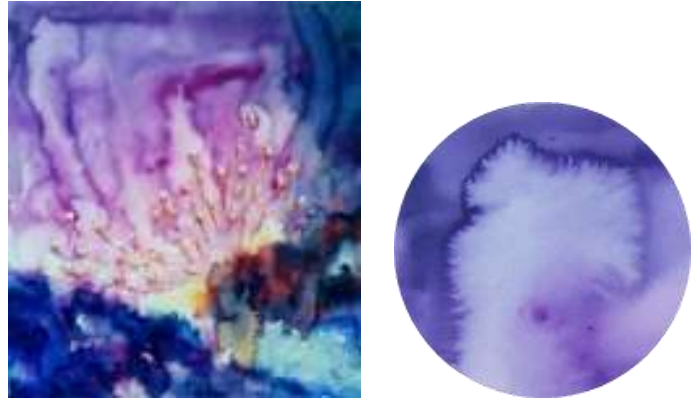

Gambar 11. Benih-Benih Berterbangan, 2016, cat air d kertas, $70 \times 70 \mathrm{~cm}$

Gambar 12. Inset teknik basah pada basah di lukisan Benih-Benih Berterbangan

\section{Teknik Lelehan Basah pada Basah}

Karya Bukit Tumbuh ini menggunakan lelehan cat encer pada kertas basah. Lukisan ini dikerjakan dalam posisi tersandar. Cat yang digoreskan kembali disemprot air, sehingga lelehannya semakin cepat. Bentuk yang diharapkan lebih jelas dikerjakan setelah kertas agak kering, bukan setelah benar-benar kering; ini untuk menjaga agar bentuk luarnya tidak terlalu tajam.
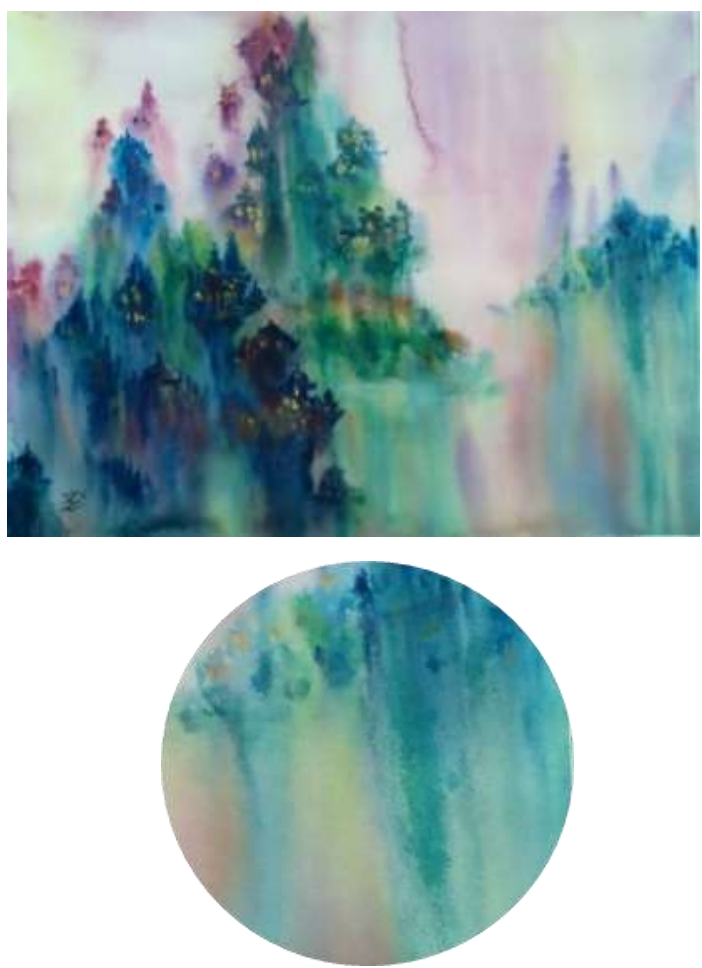

Gambar 13. Bukit Tumbuh, 2016, Cat Air di Kertas, 58 x $78 \mathrm{~cm}$

Gambar 14. Inset Teknik Lelehan Basah pada Basah dalam Lukisan Bukit Tumbuh

\section{Teknik Lelehan Kering pada Basah}

Berkebalikan dengan Bukit Tumbuh, lelehan pada lukisan berjudul Pulau Kesepian ini dikerjakan setelah kertas mengering, bukan saat masih basah. Efek yang ditimbulkan adalah bentuk lelehan yang lebih tajam atau jelas jika dibandingan dengan lelehan pada kertas basah.

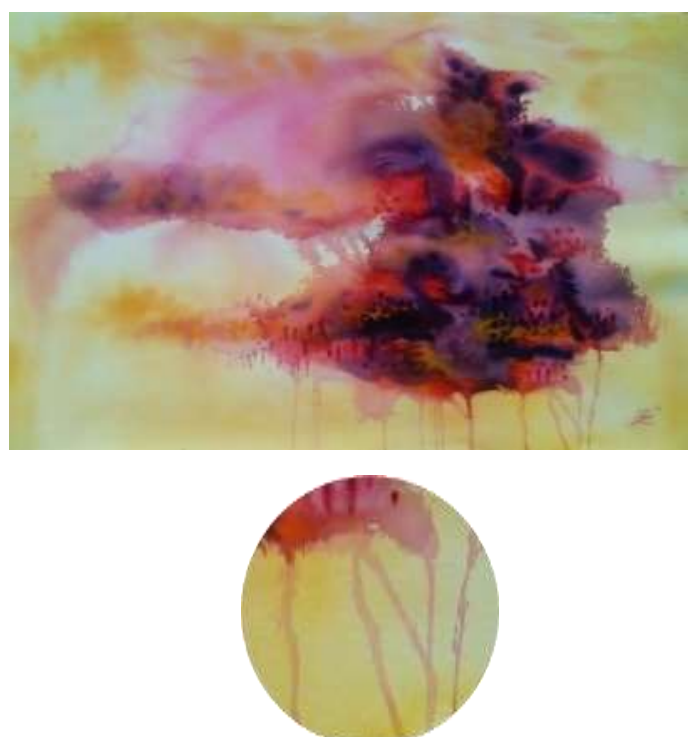

Gambar 15.Pulau Kesepian, 2016, Cat Air di Kertas, 53 x $76 \mathrm{~cm}$

Gambar 16. Inset Teknik Lelehan Kering pada Basah dalam Lukisan Pulau Kesepian

\section{Teknik Cipratan}

Lukisan Berdebur Tanpa Henti ini menggunakan efek cipatran. Cat air yang terhitung encer dicipratkan menggunakan kuas ke arah kertas kering. Cipatran dilakukan dengan cara berulang-ulang, menggunakan warna yang berbeda, dan dalam kondisi setelah warna yang lebih awal mengering. 

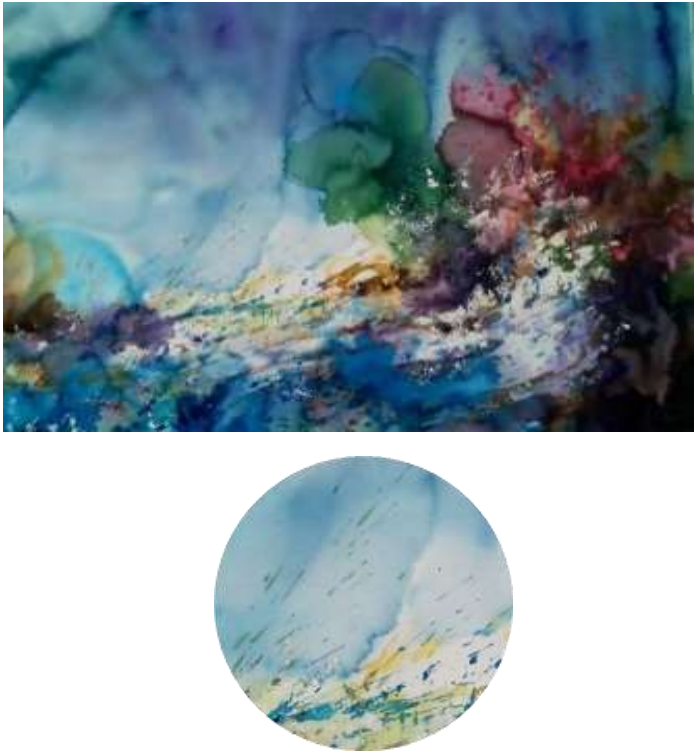

Gambar 17. Berdebur Tanpa Henti, 2016, cat air di kertas, $70 \times 100 \mathrm{~cm}$

Gambar 18. Inset teknik cipratah pada lukisan Berdebur Tanpa Henti

\section{Teknik Tiupan}

Lukisan Kota di Atas Telaga ini menggunakan efek tiupan. Pengerjaannya dengan cara menaruh cat yang cukup banyak, hingga menggelembung di kertas kering. Selanjutnya cembungan cat itu ditiup dengan karet pompa peniup yang biasa digunakan untuk membersihkan komponen komputer.
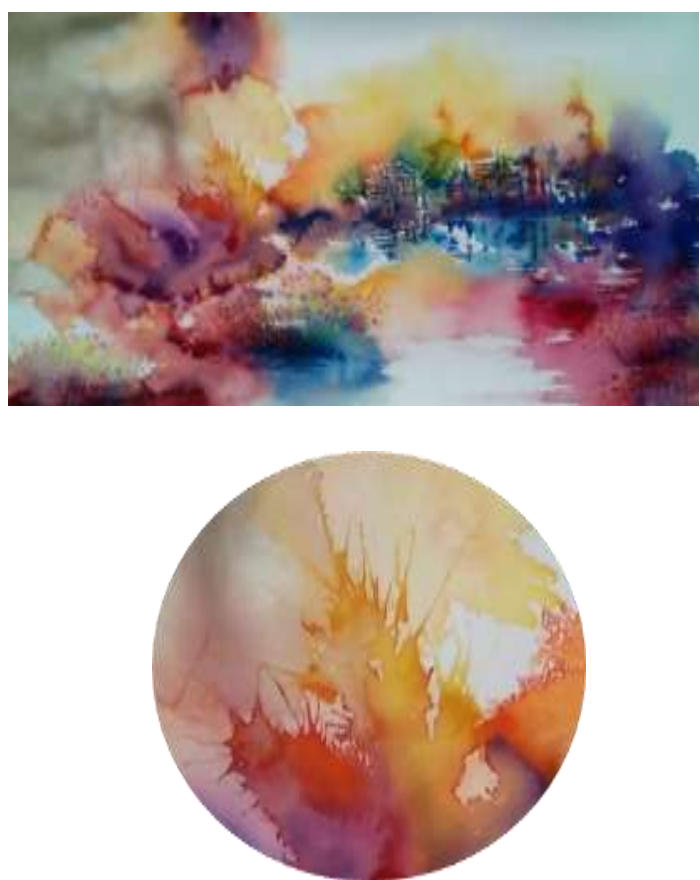

Gambar 19. Kota di Atas Telaga, 2016, Cat Air di Kertas, $60 \times 90 \mathrm{~cm}$

Gambar 20. Inset Teknik Tiupan pada Lukisan Kota di atas Telaga

\section{Teknik Penutupan}

Efek penutupan (masking) diterapkan pada lukisan Air Terjun. Sebelum membasahi kertas dengan air, bentuk yang diinginkan berwarna putih, dalam hal ini bentuk air terjun ditutup dengan art masking fluid. Selanjutnya kertas dibasahi dan digoreskan cat air. Setelah pemberian warna dirasa cukup, dan setelah kertas kembali mengering, masking dilepas. Aksentuasi warna tertentu diberikan ulang pada bentuk yang dikehendaki. Pada lukisan ini ada di warna biru muda tepatnya air terjun.
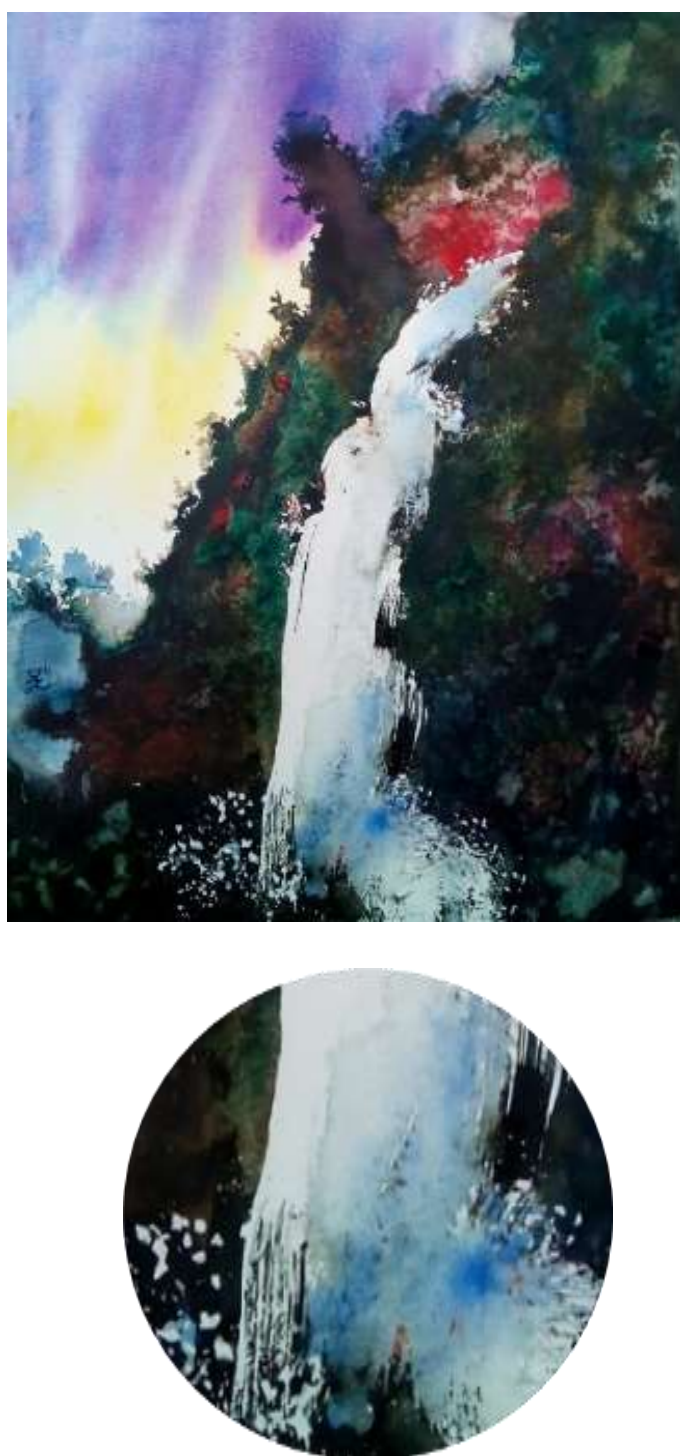

Gambar 21. Air Terjun, 2016, Cat Air di Kertas, 40,6 x $30,5 \mathrm{~cm}$

Gambar 22. Inset Teknik Penutupan pada Lukisan Air Terjun 


\section{Penciptaan Lukisan Efek Spontan Cat Air dengan Sulur Tradisional Yogyakarta}

Penciptaan lukisan kombinasi efek spontan cat air dengan sulur tradisional ini dikerjakan dengan dua cara yang berbeda. Cara pertama adalah menentukan bentuk sulur lalu diberi efek spontan cat air. Sebaliknya, cara kedua adalah membuat efek spontan cat air terlebih dahulu kemudian direspon dengan sulur.

\section{Sulur Direspon Efek Cat Air}

Pada proses 'sulur direspon cat air' ini, pertama kali adalah menentukan sulur yang akan dilukis. Lukisan pertama yang berjudul Sulur Jogja ini menggunakan data yang diperoleh dari studi pustaka, yaitu sulur Yogyakarta dalam buku Aryo Sunaryo berjudul Ornamen Nusantara Kajian Khusus tentang Ornamen Indonesia.

Tahap pertama adalah membuat sketsa sulur tersebut menggunakan pensil cat air saat kertas masih kering. Selanjutnya, masking fluid diterapkan pada bentuk yang pada hasil akhir tetap diinginkan berwarna putih. Setelah itu, kertas dibasahi, baik menggunakan kuas besar maupun penyemprot air. Dalam keadaan kertas basah, warna diterapkan. Pada umumnya, warna terang dipakai terlebih dahulu sebelum warna gelap. Lukisan Sulur Jogja ini dimulai dari warna kuning, oranye, merah, kemudian hijau.

Setelah kertas mengering, masking fluid dikelupas. Tahap selanjutnya adalah memberikan aksentuasi atau penekananpenekan garis sulur maupun warna gelap yang dikehendaki. Hal ini agar kebentukan sulur lebih teridentifikasi, meskipun pada bagian tertentu tetap dibiarkan menyatu dengan latar belakang sebagai unsur artistik gradasi bentuk.

Tahap paling akhir adalah pemberian tanda tangan. Tanda tangan ditempatkan pada komposisi yang tepat, untuk mengimbangi bentuk secara komposisional. Tanda tangan dibuat dengan warna yang harmoni dengan warna lainnya, tetapi tanda tangan tidak dibuat dengan warna yang jelas.

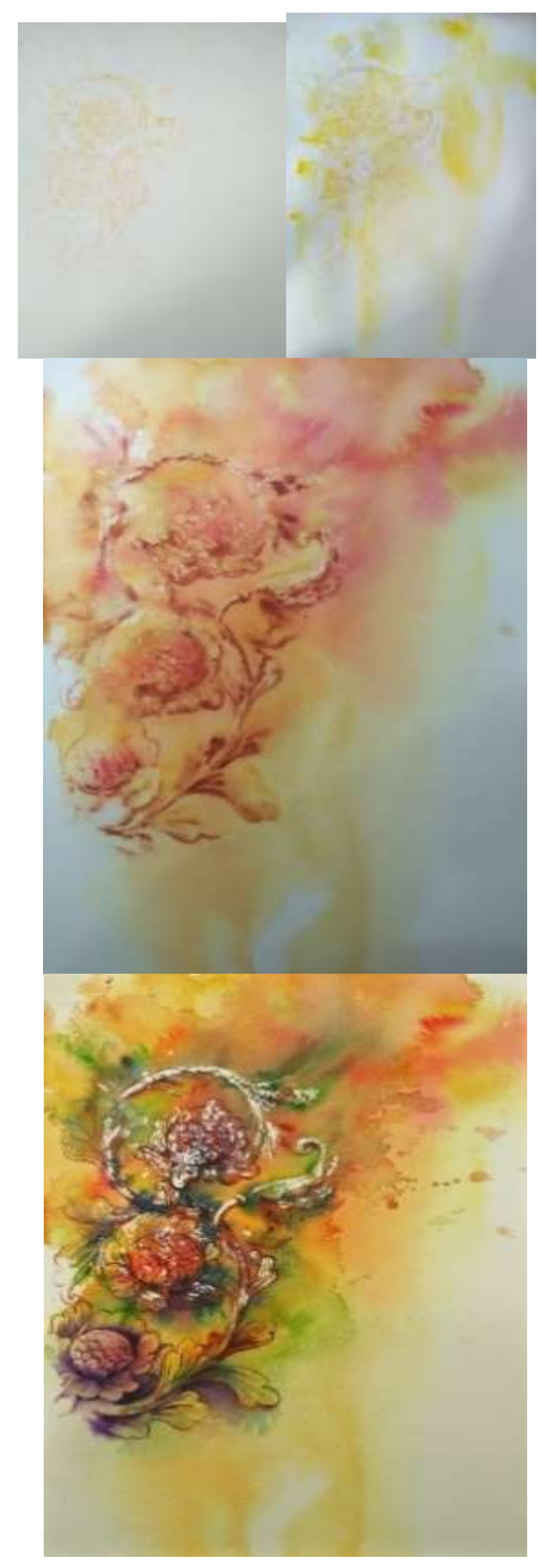

Gambar 23. Proses Pembuatan Lukisan Sulur Jogja: 1)Pembuatan Sketsa; 2) Pemberian Masking; 3) Penyemprotan Air dan Pemberian Warna Terang, Kuning; 4) Warna Oranye; 5) Warna Coklat Tua; 6) Warna Hijau; 7) Pelepasan Masking; 8) Pemberian Aksentuasi 


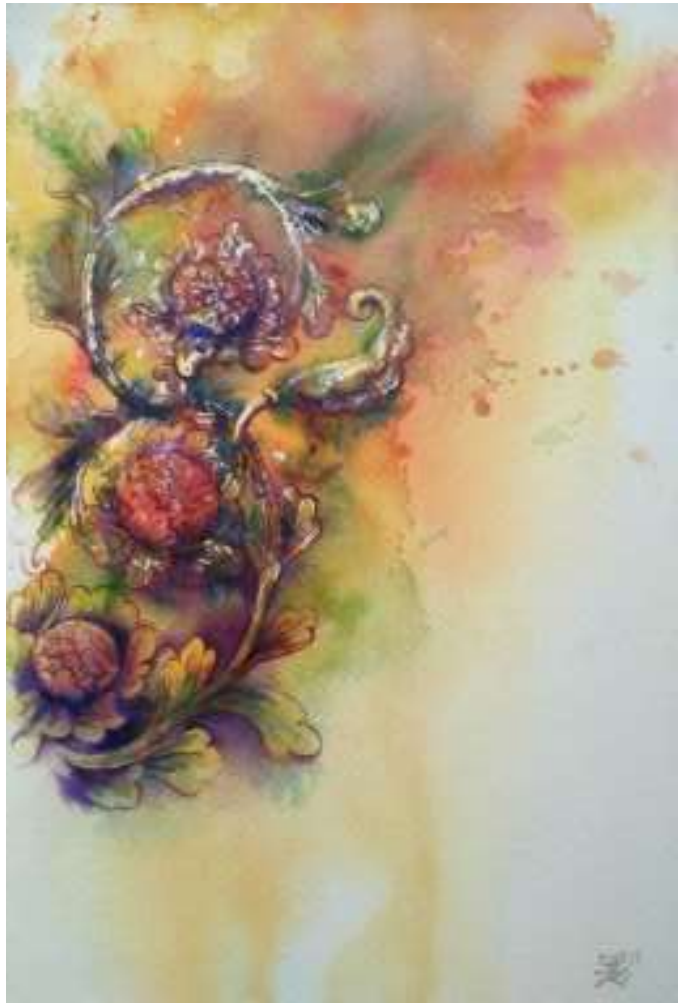

Gambar 24. Hasil Akhir Lukisan Sulur Jogja, 2017, Cat Air di Kertas, 30,5 x 45,5 cm

\section{Efek Cat Air Direspon Sulur}

Proses 'efek cat air direspon sulur' ini berkebalikan dengan cara 'sulur direspon cat air'. Pada cara ini sulur dibuat setelah efek spontan cat air terbentuk. Namun demikian, sulur yang akan dibuat untuk merespon dapat dipersiapkan terlebih dahulu. Untuk lukisan berjudul Sulur Pintu Kotagede ini menggunakan acuan sulur yang ada di pintu bangunan Makam Raja-Raja Mataram Kotagede.

Langkah pertama adalah membasahi kertas untuk mempersiapkan teknik wet on wet. Selanjutnya memberi warna muda, untuk lukisan ini adalah warna hijau muda; kesan keseluruhan yang ingin ditampilkan adalah lukisan berwarna hijau. Selanjutnya diterapkan warna hijau kebiru-biruan lalu warna tersier.

Setelah efek spontan cat air tercipta, bentuk sulur mulai dapat dibuat. Warna bernuansa hijau, dari paling muda hingga paling tua dapat digunakan. Tanda tangan dibubuhkan pada tahap akhir.
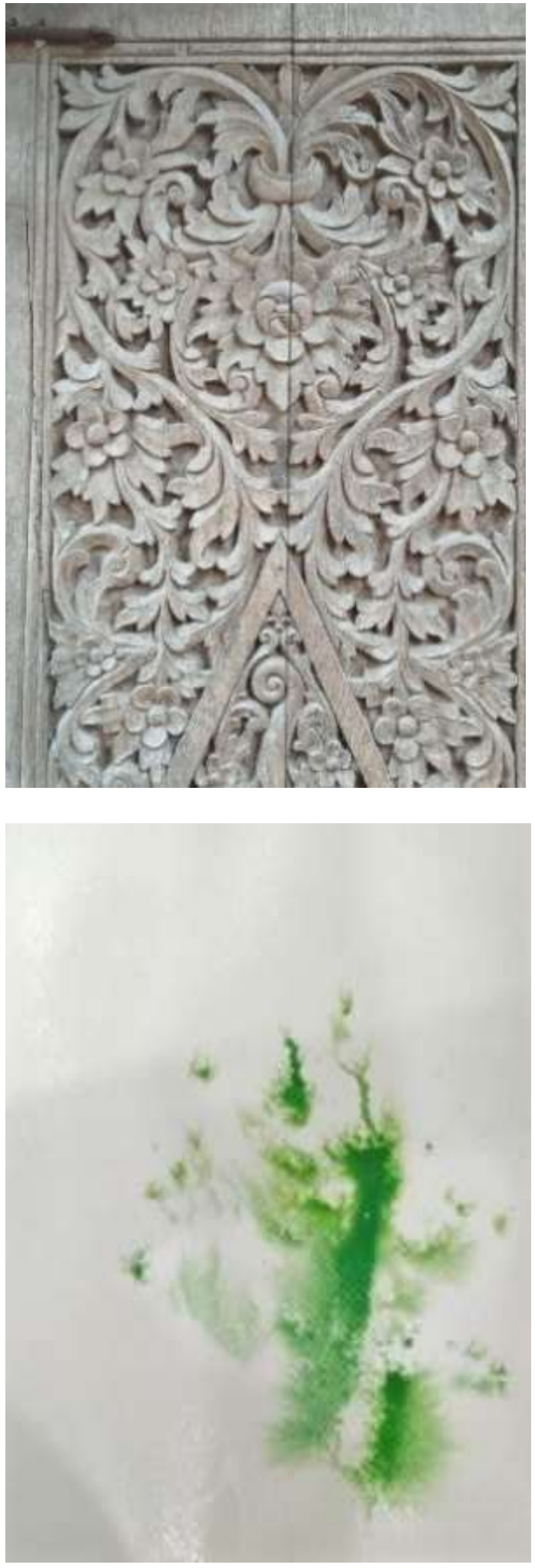

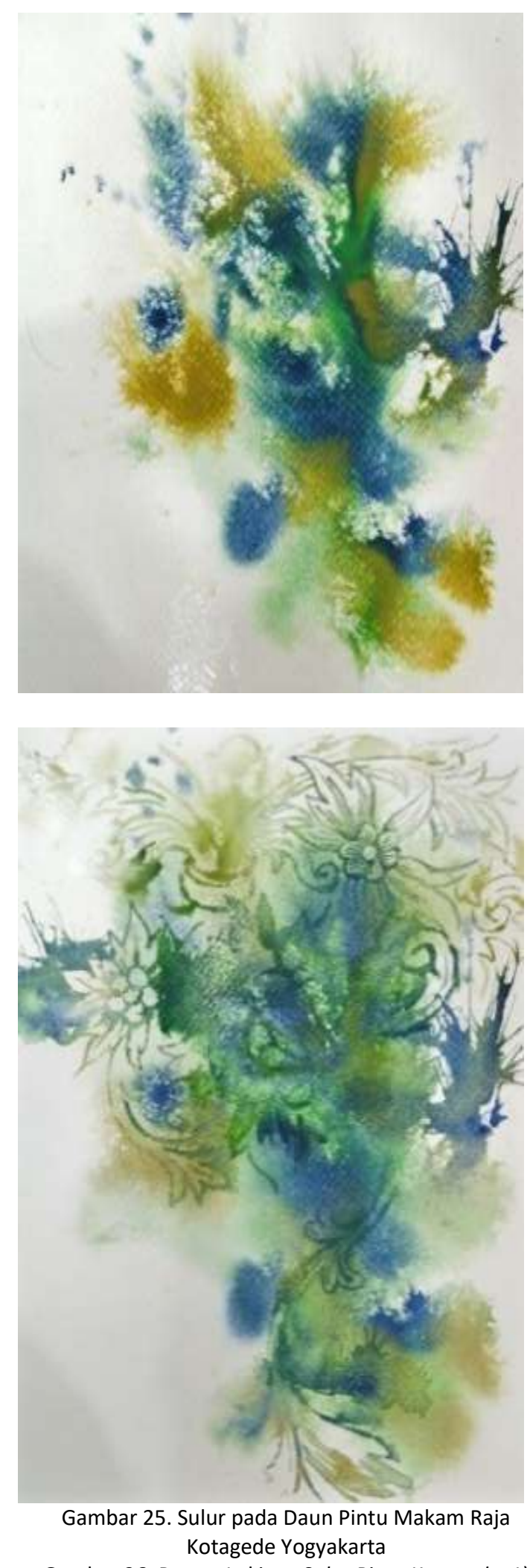

Gambar 26. Proses Lukisan Sulur Pintu Kotagede: 1) Pembasahan Kertas dan Penerapan Warna Terang, Hijau Muda; 2) Pemberian Warna Tua Hijau Kebiruan; 3) Pemberian Warna Tersier; 4) Pelukisan Sulur

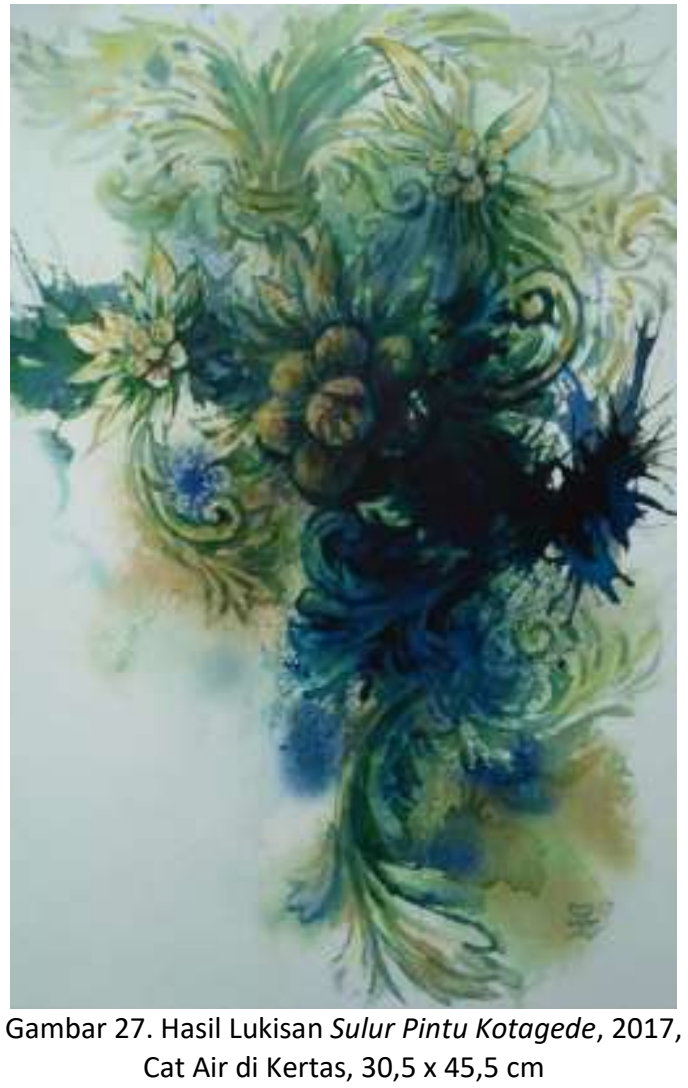

\section{DAFTAR PUSTAKA}

Aruman, Deni Junaedi, dan Isbandono Hariyanto. 2015. "Batik Postmodern (Pengadaptasian Elemen Artistik Lukisan Modern Indonesia dalam Teknik dan Motif Batik Tradisional Yogyakarta." Yogyakarta.

Dorno, Jeksi. 2014. "Bentuk dan Makna Simbolik Ornamen Ukir pada Interior Masjid Gedhe Yogyakarta." Yogyakarta.

Garcia, Joe. 2002. Mastering the Watercolor Wash. Cincinnati: North Light Books.

Mittler, Gene and Rosalind Ragans. 2005. Understanding Art. Woodland Hills: Glencoe/McGraw-Hill.

Rath, Amanda Katherine. 2010. "The Vibrating Harrow: Love and Loathing in Entang Wiharso's Recent Work." in Love Me or Die: Entang Wiharso, edited by J. Supangkat, S. Wisetrotomo, A. K. Rath, 
and S. Barry. Jakarta Utara: Galeri Canna.

Sahman, Humar. 1993. Mengenal Dunia Seni Rupa: tentang Seni, Karya Seni, Aktivitas Kreatif, Apresiasi, Kritik dan Estetika. Semarang: IKIP Semarang Press.

Sunaryo. 2009. Ornamen Nusantara Kajian Khusus tentang Ornamen Indonesia. Semarang: Dahaga Prize.

Urdea, Olimpia. 2015. "Klimt, from Painting to Fashion." in Annals of the University of Oradea Fascicle of Textiles-Leatherwork.

Wisetrotomo, Suwarno. 2016. "Run Suluk Pikir Jiwa dan Raga." in Run: the Journey of Mind, Soul and Body, edited by S. Wisetrotomo, I. Kuss, and M. Sarah. Yogyakarta: NS dan Agung Tobing.

-----------. 2012. Mengenal Wayang. Yogyakarta: Laksana.

Suseno, Frans Magnes, 1995. Wayang dan Panggilan Manusia Jawa. Jakarta: Gramedia Pustaka Utama.

Sutrisno, Slamet dkk. 2009. Filsafat Wayang. Jakarta: Sena Wangi.

Zarkasi, Effendi. 1996. Unsur-Unsur Islam dalam Pewayangan Telaah terhadap Penghargaan Walisanga terhadap Wayang untuk Media Dakwah Islam. Solo: Yayasan Mardikintoko. 